\title{
Agronomic management of lentil under relay cropping system
}

\author{
Sanjib Kumar Mandi*, Md Hasim Reja, Milan Kanti Kundu, Srijani Maji, Rajib Nath, \\ Sukanta Das and Ashutosh Sarker ${ }^{1}$
}

Department of Agronomy, Bidhan Chandra Krishi Viswavidyalaya, Mohanpur, Nadia-741 252, West Bengal, India.

Received: 28-08-2017

Accepted: 27-09-2017

DOI: 10.18805/IJARe.A-4884

\begin{abstract}
A field experiment was conducted at District Seed Farm, Kalyani, Bidhan Chandra Krishi Viswavidyalaya $\left(22.97^{\circ} \mathrm{N}, 88.43^{\circ} \mathrm{E}\right.$, 9.75m MSL), Nadia, West Bengal, India during rabi season of 2014-16 to identify the optimum seed rate and variety for relay cropping with transplanted long duration kharif rice under changing onset of monsoon. The experiment was laid down in split plot design with three replications comprising of three lentil varieties (PL6, WBL 77 and NDL 1) in main plot and four seed rates $\left(50,60,70\right.$ and $\left.80 \mathrm{~kg} \mathrm{ha}^{-1}\right)$ in sub-plot. The varieties and seed rates significantly affected the plant population, pods per plant, biological and seed yield. The lentil variety PL 6 recorded highest seed yield $\left(1446.8 \mathrm{~kg} \mathrm{ha}^{-1}\right)$ with the seed rate of $60 \mathrm{~kg} \mathrm{ha}^{-1}$ followed by WBL 77 and NDL 1. Among the varieties PL6 recorded highest test weight $(27.58 \mathrm{~g})$ followed by NDL $1(18.36 \mathrm{~g})$ and WBL $77(16.20 \mathrm{~g})$. The variety PL 6 exhibited highest seed yield which was mainly attributed by the highest test weight of seeds along with moderate plant population $\mathrm{m}^{-2}$ and number of pods plant $\mathrm{t}^{-1}$.
\end{abstract}

Key words: Lentil, Long duration rice, Relay cropping, Seed rate, Variety.

\section{INTRODUCTION}

Pulses are indispensable sources of dietary protein and contribute to the recycling of atmospheric nitrogen cycle through the active participation of Rhizobium sp. Among the winter pulses lentil (Lens culinaris Medik.) is one of the most nutritious ( $25 \%$ protein) grain legume and ranks next only to chickpea in India. It occupies 1.80 million ha area with a production of 1.10 million tonnes and productivity of $611 \mathrm{~kg} \mathrm{ha}^{-1}$ (FAOSTAT, 2014). The aberrant onset and withdrawal of monsoon often poses problem in the land preparation of the winter crops (Parya et al., 2010). In West Bengal, lentil seeds are often broadcasted (as relay crop) in the standing crop of rice 15-20 days before harvesting (DBH) to capitalize residual soil moisture and ensure timely sowing for optimum germination and skipping off the tillage operations during lentil growing. However, the sowing of lentil often gets delayed due to weather variability and infestation of pest and diseases which lowers the yield. Late sown lentil faces terminal heat stress and drought during pod filling stage resulting in poor yield (Ali et al., 2012). Under such situation, early maturing cultivars with early vigour, fast vegetative growth and quick canopy coverage may be successfully grown as relay crop in standing rice crop under no tillage condition. This further ensures conservation of natural resources, reduction of cost of cultivation as there is no need of land preparation and other farm operations. The present experiment was carried out to identify the optimum seed rate and suitable lentil varieties for relay cropping with long duration kharif rice (MTU 7029) under changing onset and cessation of monsoon.

\section{MATERIALS AND METHODS}

A field experiment was conducted at District Seed Farm ('AB' Block), Bidhan Chandra Krishi Viswavidyalaya, Kalyani $\left(22.97^{\circ} \mathrm{N}, 88.43^{\circ} \mathrm{E}, 9.75 \mathrm{~m} \mathrm{MSL}\right.$ ), Nadia (New Alluvial Zone), West Bengal, India to study the effect of varieties and seed rates on growth, yield and yield components of lentil under relay cropping with long duration rice variety (MTU 7029) during 2014 -15 to 2015-16. The experimental site falls under tropical humid climate and experiences three distinct seasons- March to May as summer, June to September as rainy season and October to February as winter; the summer season is humid and receives rainfall with thunderstorm occasionally. Generally the monsoon starts in the area by the second week of June with some natural variation among different years while the onset may be delayed up to last week of June in some years. The long-term of which $70-80 \%$ accounts from the south-west monsoon. Maximum relative humidity follows a range of \pm 80 to \pm 90 percent throughout the year, usually having the higher extremes during the wet season. During the experimental period, the maximum relative humidity varied ranged from 89.6 to $92.9 \%$ and 87.9 to $98.1 \%$ while minimum relative humidity ranged from 42.6 to $68.7 \%$ and 46.6 to $57.5 \%$ during the experimentation period of 2014-15 and 2015-16 respectively (Table 1 and Table 2). The mean annual

*Corresponding author's e-mail: sengelsarsanjib@gmail.com, mandi.sanjib@bckv.edu.in

${ }^{1}$ ICARDA - South Asia and China Regional Programme, New Delhi - 110012, India. 
Table 1: Meteorological data pertaining to the period of experimentation (July, 2014 to March, 2015)

\begin{tabular}{|c|c|c|c|c|c|c|}
\hline \multirow[t]{2}{*}{ Month } & \multicolumn{2}{|c|}{ Temperature $\left({ }^{\circ} \mathrm{C}\right)$} & \multicolumn{2}{|c|}{ Relative humidity (\%) } & \multirow[t]{2}{*}{ Rainfall (mm) } & \multirow{2}{*}{\begin{tabular}{c}
\multicolumn{2}{c}{ Bright } \\
sunshine (hour)
\end{tabular}} \\
\hline & Max. & Min. & Max. & Min. & & \\
\hline July & 32.85 & 26.95 & 96 & 83.5 & 237.1 & 3.65 \\
\hline August & 34.08 & 26.45 & 95 & 77.6 & 348.2 & 4.7 \\
\hline September & 34.175 & 25.875 & 94 & 77 & 281.7 & 6.475 \\
\hline October & 33.825 & 23.5 & 87.75 & 69 & 81.9 & 7 \\
\hline November & 32.08 & 16.14 & 80.6 & 51.8 & 0 & 7.32 \\
\hline December & 26.525 & 12 & 86.25 & 57.5 & 0 & 5.35 \\
\hline January & 26.65 & 11.6 & 87.75 & 58.25 & 2.5 & 6.2 \\
\hline February & 30.55 & 14.7 & 82.25 & 48.5 & 13.6 & 6.45 \\
\hline March & 35.6 & 18.35 & 80.25 & 37.25 & 21.4 & 9.025 \\
\hline
\end{tabular}

(Source: AICRP on Agro-Meteorology, Directorate of Research, B.C.K.V. Kalyani, Nadia, West Bengal)

Table 2: Meteorological data pertaining to the period of experimentation (July, 2015 to March, 2016)

\begin{tabular}{|c|c|c|c|c|c|c|}
\hline \multirow[t]{2}{*}{ Month } & \multicolumn{2}{|c|}{ Temperature $\left({ }^{\circ} \mathrm{C}\right)$} & \multicolumn{2}{|c|}{ Relative humidity (\%) } & \multirow[t]{2}{*}{ Rainfall (mm) } & \multirow[t]{2}{*}{ Bright sunshine (hour) } \\
\hline & Max. & Min. & Max. & Min. & & \\
\hline July & 32.45 & 26.55 & 98.25 & 86 & 406.4 & 2.5 \\
\hline August & 32.42 & 26.64 & 94.80 & 77.4 & 252.7 & 3.9 \\
\hline September & 34.075 & 26.15 & 95.75 & 70 & 205.1 & 5.7 \\
\hline October & 33.675 & 24 & 94 & 62.25 & 42.1 & 7.675 \\
\hline November & 31.3 & 19.2 & 93.4 & 54.8 & 0 & 6.3 \\
\hline December & 26.025 & 14.725 & 93.75 & 56 & 6.6 & 3.375 \\
\hline January & 25.6 & 11.65 & 92.75 & 53.25 & 3 & 4.45 \\
\hline February & 30.4 & 17.3 & 92.25 & 52.5 & 15 & 5.275 \\
\hline March & 33.7 & 21.15 & 91.75 & 48.5 & 49.3 & 7.275 \\
\hline
\end{tabular}

(Source: AICRP on Agro-Meteorology, Directorate of Research, B.C.K.V. Kalyani, Nadia, West Bengal)

temperature falls below $20^{\circ} \mathrm{C}$ in November and continues till the early part of February. The winter is thus mild and short in the New Alluvial Zone of West Bengal. The experiment was conducted on a medium land, well-drained Gangetic alluvial soil (order: Inceptisol), which belonged to the class of clayey loam with medium fertility and almost neutral in soil reaction. The experiment was laid down in split plot design with three replications comprising of three varieties $\left(\mathrm{V}_{1}=\mathrm{PL6}, \mathrm{V}_{2}=\mathrm{WBL} 77\right.$ and $\left.\mathrm{V}_{3}=\mathrm{NDL} 1\right)$ and four seed rates $\left(\mathrm{S}_{1}=50 \mathrm{~kg} \mathrm{ha}^{-1}, \mathrm{~S}_{2}=60 \mathrm{~kg} \mathrm{ha}^{-1}, \mathrm{~S}_{3}=70 \mathrm{~kg} \mathrm{ha}^{-1}\right.$ and $\mathrm{S}_{4}=$ $\left.80 \mathrm{~kg} \mathrm{ha}^{-1}\right)$. Lentil varieties were placed in the main-plot and different seed rates in sub-plot. Rice seedling was transplanted on $27^{\text {th }}$ and $22^{\text {nd }}$ July in 2014 and 2015 respectively with $80 \mathrm{~kg} \mathrm{ha}^{-1}$ Nitrogen, $40 \mathrm{~kg} \mathrm{ha}^{-1}$ Phosphorous and $40 \mathrm{~kg} \mathrm{ha}^{-1}$ Potassium. Nitrogen was applied in three split doses $\left(1 / 2^{\text {th }}\right.$ at basal, $1 / 4^{\text {th }}$ at $1^{\text {st }}$ top dressing and rest at $2^{\text {nd }}$ top dressing) and full dose of Phosphorous and Potassium were applied at basal. Harvesting of rice was done on $26^{\text {th }}$ and $24^{\text {th }}$ November in 2014 and 2015 respectively, leaving $25 \mathrm{~cm}$ straw height from the base. Lentil seeds were broadcasted on $11^{\text {th }}$ and $9^{\text {th }}$ November in $1^{\text {st }}$ and $2^{\text {nd }}$ year respectively during rabi (winter) season. The sub-plot size was $4 \mathrm{~m} \times 2 \mathrm{~m}$ with $1 \mathrm{~m}$ spacing between replications, $0.6 \mathrm{~m}$ between main plots and $0.5 \mathrm{~m}$ spacing between sub-plots.
Total numbers of plots were 36 in the experiment. Lentil seeds were broadcasted as per treatment in the transplanted monsoon rice field before 15 days of rice harvest after draining out the excess water. Lentil seeds were soaked overnight before sowing. Fertilizer doses applied were 20$40-20 \mathrm{~kg} \mathrm{ha}^{-1}$ of $\mathrm{N}, \mathrm{P}_{2} \mathrm{O}_{5}$ and $\mathrm{K}_{2} \mathrm{O}$ respectively. $\mathrm{P}$ and $\mathrm{K}$ fertilizers were broadcasted during sowing and $\mathrm{N}$ fertilizer was applied after harvesting of rice. Foliar application of $2 \%$ urea and $0.1 \%$ boron was followed at pre-flowering and pod development stages. Intercultural operations were done whenever required. Finally, lentil was harvested on $11^{\text {th }}$ and $7^{\text {th }}$ March in 2015 and 2016 (120 and 119 days after sowing) respectively, when $80 \%$ pod and plants were turned to straw colour. Five plants from each plot were collected at random and kept aside during harvest area for recording the data of yield parameters. After harvesting of the crop, it was kept under sun for drying and then threshing was done using a stick. Grain and straw were separated by winnowing. Then the grain and straw was adjusted at $9 \%$ moisture content. Finally plot wise grain and straw yield were converted into $\mathrm{kg} \mathrm{ha}^{-1}$. Soil was collected before sowing and after harvesting of crop Table 3). The recorded data were compiled and tabulated for statistical analysis (Gomez and Gomez, 1984).

Table 3: Soil fertility status of initial and after lentil relay cropping

\begin{tabular}{lccccc}
\hline Fertility status (Pooled) & $\mathbf{p H}$ & $\begin{array}{c}\text { Organic carbon } \\
\mathbf{( \% )}\end{array}$ & $\begin{array}{c}\text { Available } \\
\text { nitrogen }\left(\mathbf{k g ~ h a}^{-1}\right)\end{array}$ & $\begin{array}{c}\text { Available } \\
\text { phosphorus (kg ha-1) }\end{array}$ & $\begin{array}{c}\text { Available } \\
\text { potassium (kg ha-1) }^{-1}\end{array}$ \\
\hline Initial & 7.3 & 0.50 & 184.5 & 28.63 & 182.3 \\
Final & 7.2 & 0.53 & 197.4 & 32.99 & 182.6 \\
\hline
\end{tabular}




\section{RESULTS AND DISCUSSIONS}

Plant height: Pooled analysis of two years data revealed that the variety PL6 exhibited significantly highest mean plant height $(51.1 \mathrm{~cm})$ followed by NDL 1 (Table 4). No significant variation was observed when seed rate was considered, though $60 \mathrm{~kg} \mathrm{ha}^{-1}$ seed rate gave highest plant height $(51.5 \mathrm{~cm})$ at the time of harvesting. No significant variation in plant height was observed when interaction values were considered, but $\mathrm{V}_{1} \mathrm{~S}_{2}$ treatment exhibited highest plant height $(55.1 \mathrm{~cm})$ and $\mathrm{V}_{2} \mathrm{~S}_{3}$ treatment recorded the lowest plant height $(44.6 \mathrm{~cm})$.

Plant population per square metre: There was significant difference in plant population among the varieties (Table 4). Lentil variety WBL 77 exhibited highest mean plant population (203 plants $\mathrm{m}^{-2}$ ) followed by PL 6 and NDL 1 . Plant population was significantly varied in both the years (2014-15 and 2015-16) as well as when pooled data were considered. The treatment $\mathrm{S}_{4}\left(80 \mathrm{~kg} \mathrm{ha}^{-1}\right)$ exhibited significantly highest plant population $\left(214\right.$ plants $\left.\mathrm{m}^{-2}\right)$ in both the years followed by treatment $S_{1}\left(50 \mathrm{~kg} \mathrm{ha}^{-1}\right)$ and $\mathrm{S}_{3}(70 \mathrm{~kg}$ $\mathrm{ha}^{-1}$ ) where plant population was 180 plants $\mathrm{m}^{-2}$. Although there was no significant variation in plant population among different treatment combinations in both the years but it was observed that pooled values varied significantly and $\mathrm{V}_{2} \mathrm{~S}_{4}$ exhibited highest plant population $\left(255\right.$ plants $\left.\mathrm{m}^{-2}\right)$. Ali et al. (2012) reported that, plant population per $\mathrm{m}^{2}$ of lentil under relay cropping ranged in 163 to 323 .

Number of branches per plant: Number of total branches at the time of harvesting was more or less similar in both the years. The variety NDL1 exhibited highest branches plant ${ }^{-1}$ in both the years (13 and 7) as well as when pooled data were considered. The variety NDL 1 showed significant variation with PL 6 and WBL 77. When seed rate was considered the treatment $S_{3}\left(70 \mathrm{~kg} \mathrm{ha}^{-1}\right)$ recorded highest branches $\left(10\right.$ plant $\left.^{-1}\right)$. No significant variation was observed among different seed rates. The $\mathrm{V}_{3} \mathrm{~S}_{1}$ treatment combination exhibited highest branches plant ${ }^{-1}(11)$ followed by $\mathrm{V}_{3} \mathrm{~S}_{3}$, $\mathrm{V}_{3} \mathrm{~S}_{4}$ and $\mathrm{V}_{2} \mathrm{~S}_{3}$. Higher number of branches plant ${ }^{-1}$ were observed in 2014-'15 which might be due to congenial environmental condition. There were no significant variations when interaction values were considered.

Number of pods per plant: In pulse crop number of pods plant $^{-1}$ is most important determinant of seed yield. Among the varieties, WBL 77 exhibited highest number of mean pods per plant (64) followed by PL 6 (60) and NDL1 (54) when pooled data (Table 4) were considered. The highest number of pods per plant (75) appeared with the seed rate of $60 \mathrm{~kg} \mathrm{ha}^{-1}$ followed by 58 pods per plant with $70 \mathrm{~kg} \mathrm{ha}^{-1}$ seed rate. Significant variation was observed among the mean values in both the experimental years as well as when pooled values were considered. The number of pods per plant in three varieties were in the order of WBL77 > PL6 > NDL1 at $60 \mathrm{~kg} \mathrm{ha}^{-1}$ seed rate. The higher number of pods per plant was observed in the first year as compared to second year due to better environmental condition during crop growth stage (Fig. 1). The lower seed rate facilitated better canopy development and interception of light resulting in higher number of pods per plant (Ali et al., 2014). However, this important yield attribute also varied due to genotype and spacing (Singh et al., 1991).

Seed yield: The variety PL 6 exhibited significantly highest mean seed yield (1249.8 $\left.\mathrm{kg} \mathrm{ha}^{-1}\right)$ followed by WBL 77 $\left(1155.2 \mathrm{~kg} \mathrm{ha}^{-1}\right)$. When seed rate was considered, the treatment $\mathrm{S}_{2}\left(60 \mathrm{~kg} \mathrm{ha}^{-1}\right)$ exhibited highest mean seed yield $\left(1302.2 \mathrm{~kg} \mathrm{ha}^{-1}\right)$ followed by $\mathrm{S}_{4}\left(80 \mathrm{~kg} \mathrm{ha}^{-1}\right)$ treatment (1194.5 $\mathrm{kg} \mathrm{ha}^{-1}$ ) due to the highest number of pods per plant (Table 5). Significant variation was observed among mean values. Parveen et al. (2010) observed the similar results. El-Nagar (2002) reported that seeding rates had high positive effect on plant height, seed yield per ha, harvest index and nitrogen

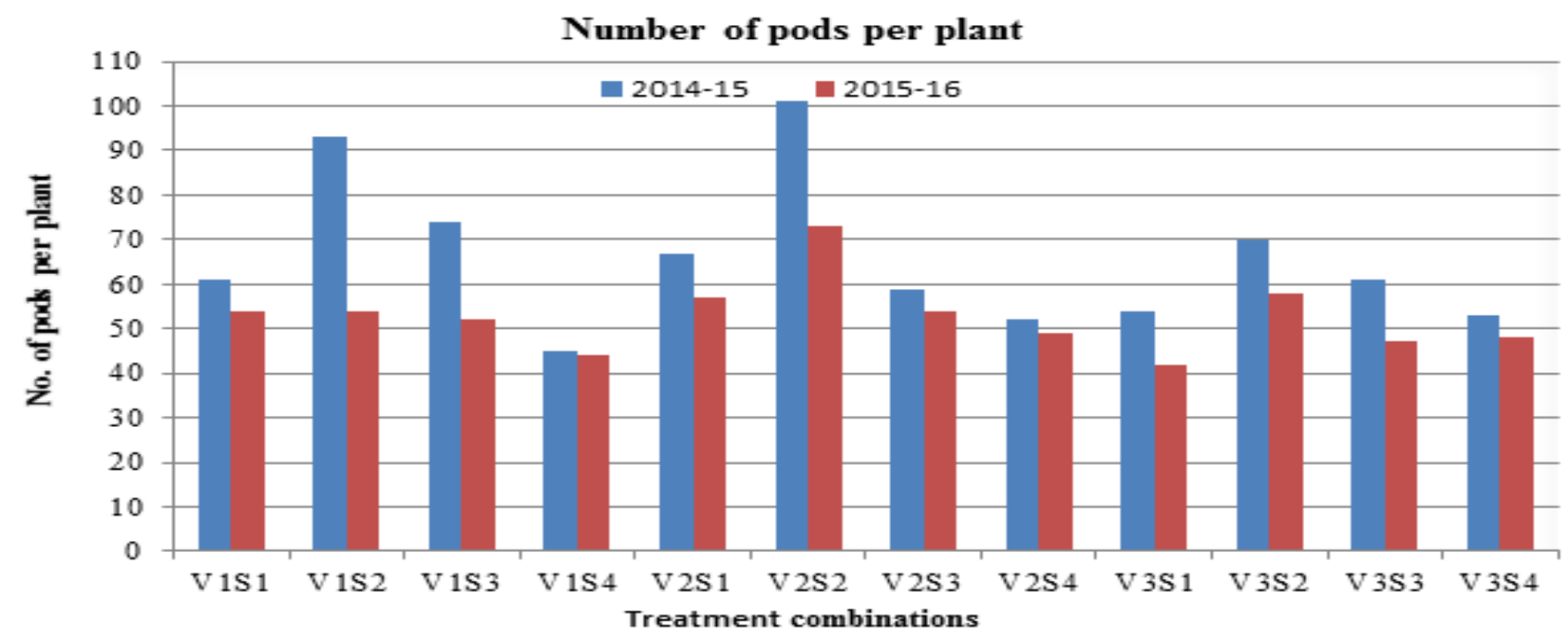

Fig-1: Number of pods per plant under different treatment combinations in relay lentil 
Volume 51 Issue 6 (December 2017)

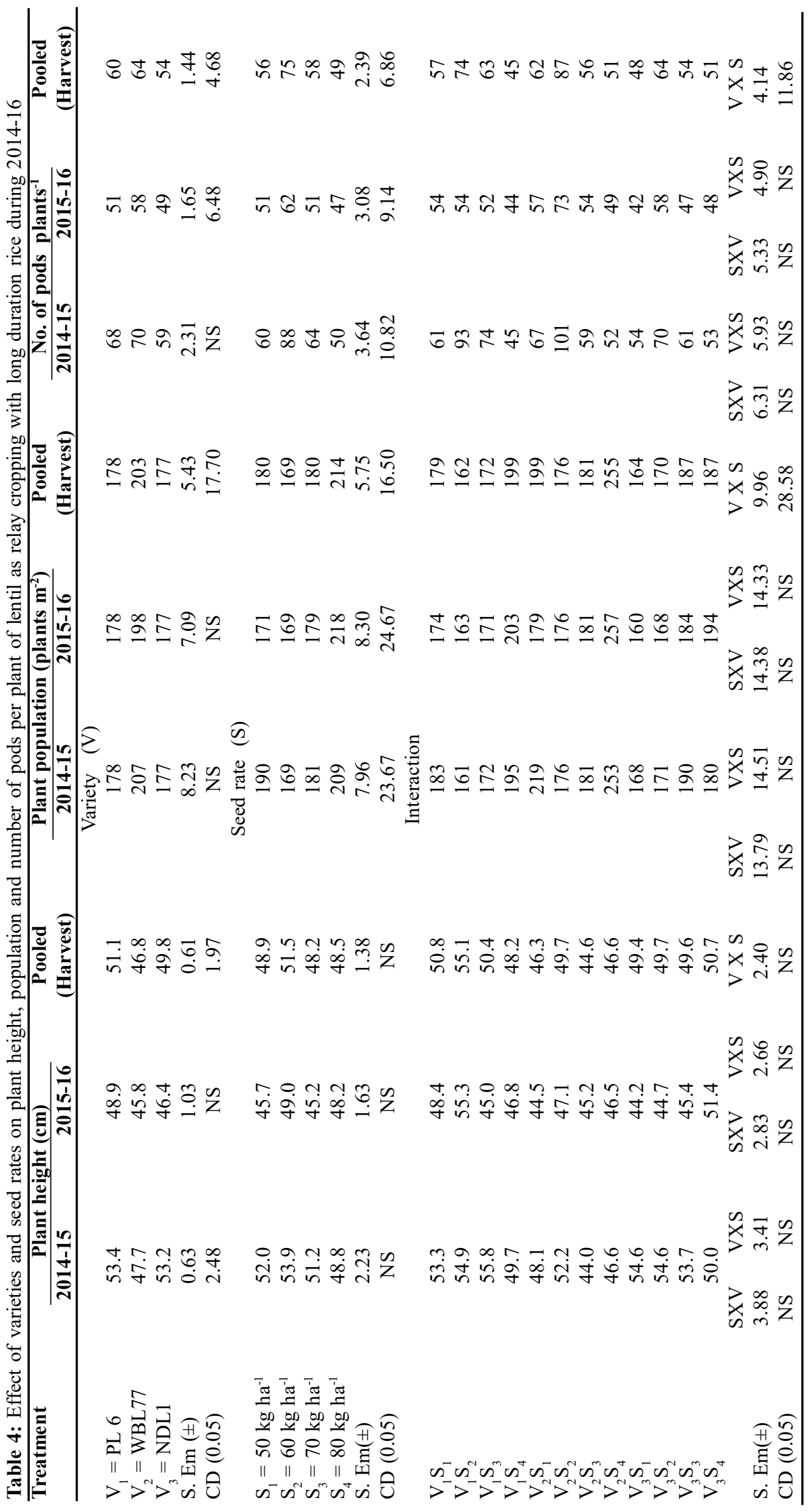




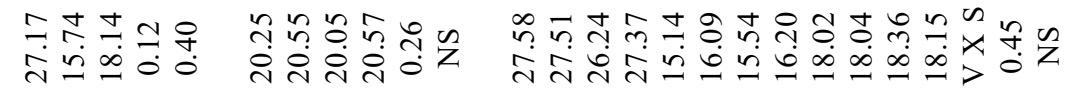

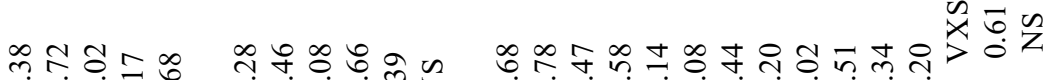

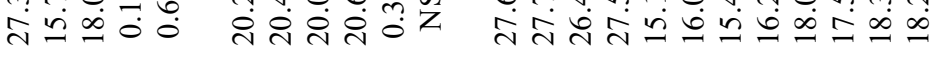

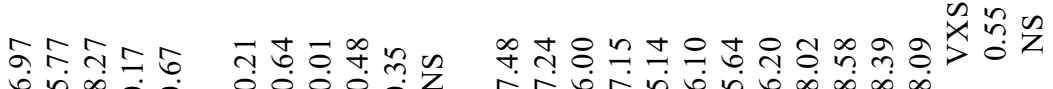

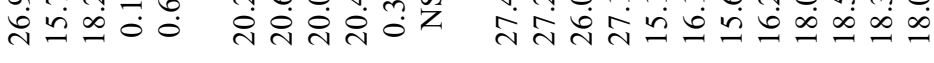

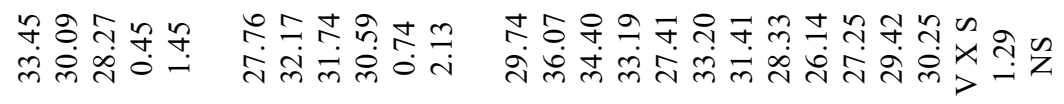

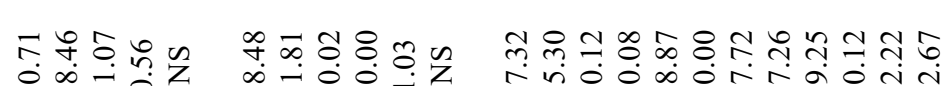

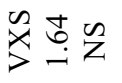

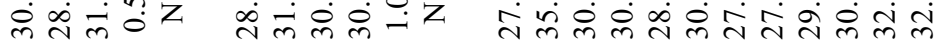

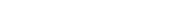

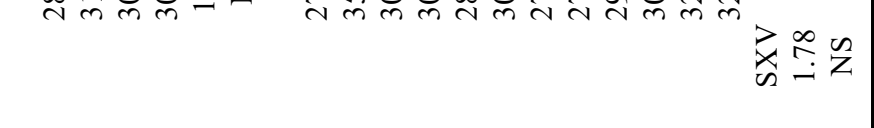

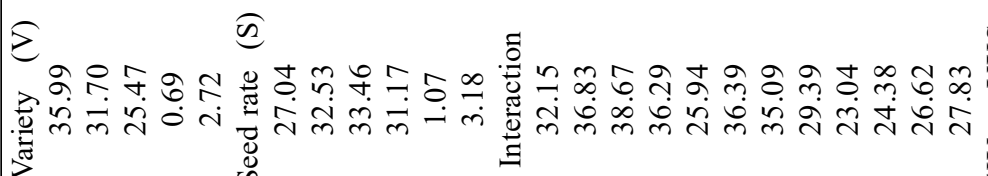

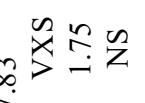
忞象里

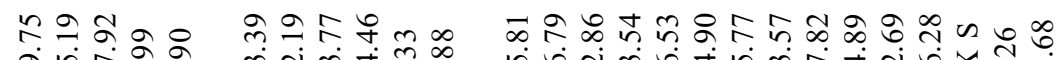

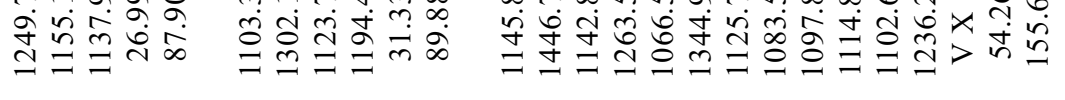

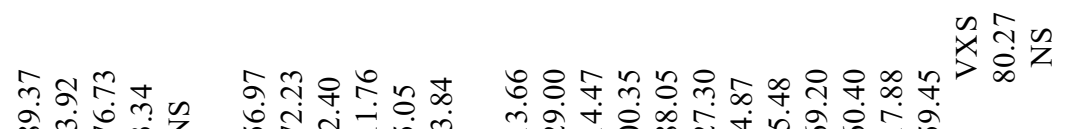

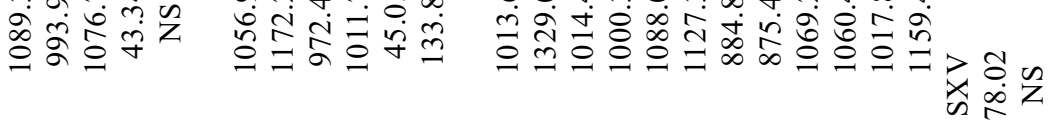

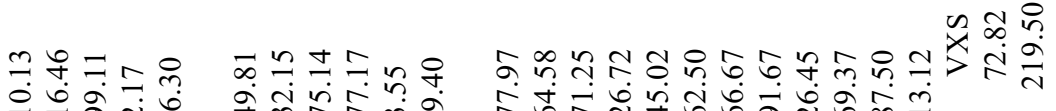

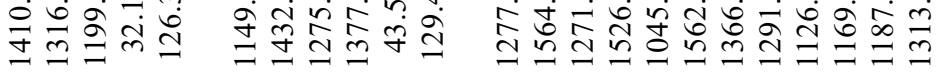

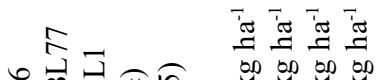

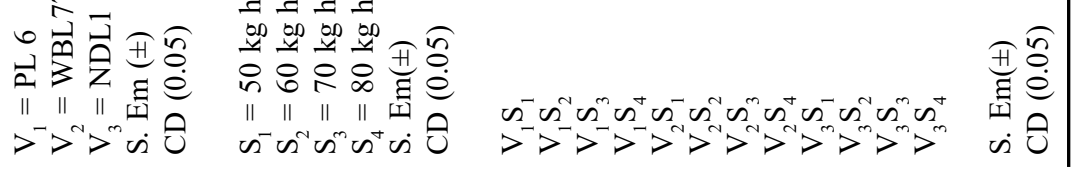


recovery, but had high significant negative effects on the number of branches per plant, dry matter per plant, number of pods per plant, test weight, protein content and phosphorus percentage.

The variety PL 6 (1446.8 $\left.\mathrm{kg} \mathrm{ha}^{-1}\right)$ recorded significantly the highest seed yield followed by WBL 77 (1344.9 $\mathrm{kg} \mathrm{ha}^{-1}$ ) both under $60 \mathrm{~kg} \mathrm{ha}^{-1}$ seed rate (Table 5). However, the variety NDL1 recorded maximum seed yield of $1236.3 \mathrm{~kg} \mathrm{ha}^{-1}$ under $80 \mathrm{~kg} \mathrm{ha}^{-1}$ of seed rate. Significant variations were observed among mean values under different treatment combination. Though WBL 77 recorded highest biological yield and number of pods per plant, medium to bold seeded PL 6 recorded the highest seed yield due to higher mean test weight. Materne et al. (2009) reported that significant interaction between genotype and agronomic manipulation determined yield. Ayaz (2001) reported that, positive, linear and significant relationship between seed yield and total dry matter of grain legumes.

It is interesting to note that the lentil crop gave higher yield irrespective of varieties and seed rate when relay cropped with long duration rice. The higher seed yield was recorded in the first year as compared to the second year (Fig. 2). This was probably due to the rainfall received during end of October which provided favourable soil moisture regime after long duration rice and facilitated better germination and crop stand of lentil.

Biological Yield: The highest mean biological yield (4129.0 $\mathrm{kg} \mathrm{ha}^{-1}$ ) was observed in the variety NDL1 followed by the variety WBL77 that yielded $3814.5 \mathrm{~kg} \mathrm{ha}^{-1}$. No significant variation was observed when pooled data were considered but the biological yield was significantly varied in the first year. In case of seed rate variations, highest mean biological yield $\left(4066.1 \mathrm{~kg} \mathrm{ha}^{-1}\right)$ was observed with the seed rate of 60 $\mathrm{kg} \mathrm{ha}^{-1}$ followed by $4043.3 \mathrm{~kg} \mathrm{ha}^{-1}$ under $50 \mathrm{~kg} \mathrm{ha}^{-1}$ seed rate.
Significant variations were observed among the different seed rates when pooled data were considered. Parveen et al. (2010) reported that seed rate of $60 \mathrm{~kg} \mathrm{ha}^{-1}$ gave the highest straw yield (2.98 $\left.\mathrm{t} \mathrm{ha}^{-1}\right)$ and the highest biological yield (4.41 $\left.\mathrm{tha}^{-1}\right)$.

The variety NDL 1 exhibited highest biological yield (4350.5 kg ha-1) under $50 \mathrm{~kg} \mathrm{ha}^{-1}$ seed rate followed by the seed rate of $60 \mathrm{~kg} \mathrm{ha}^{-1}\left(4175.3 \mathrm{~kg} \mathrm{ha}^{-1}\right)$. No significant variations were observed among different treatment combinations in both the experimental years. The lowest biological yield (3328.2 $\mathrm{kg} \mathrm{ha}^{-1}$ ) was observed with the seed rate of $70 \mathrm{~kg} \mathrm{ha}^{-1}$ when the variety PL 6 was considered.

Harvest index: The result showed that PL 6 exhibited highest harvest index (33.5\%) followed by WBL 77 (30.1\%) when pooled values were considered (Table 5). Significant variation was observed among mean values. The seed rate of $60 \mathrm{~kg} \mathrm{ha}^{-1}$ recorded highest $(32.2 \%)$ harvest index followed by the treatment $\mathrm{S}_{3}(31.7 \%)$. The lowest harvest index was observed $(27.8 \%)$ with the seed rate of $50 \mathrm{~kg} \mathrm{ha}^{-1}$. Significant variation was observed among mean values under different seed rates. The variety PL 6 recorded highest harvest index $(36.1 \%)$ under $60 \mathrm{~kg} \mathrm{ha}^{-1}$ of seed rate followed by the same variety $(34.4 \%)$ under $70 \mathrm{~kg} \mathrm{ha}^{-1}$ of seed rate. The variety WBL 77 gave highest harvest index (33.2\%) under $60 \mathrm{~kg} \mathrm{ha}^{-1}$ of seed rate. NDL 1 exhibited highest harvest index $(30.3 \%)$ under $80 \mathrm{~kg} \mathrm{ha}^{-1}$ seed rate. The mean values did not varied significantly among themselves under different treatment combinations.

Test weight: The result showed that the variety PL 6 recorded significantly highest test weight $(27.2 \mathrm{~g})$ followed by NDL $1(18.1 \mathrm{~g})$ in both the experimental years as well as when pooled data were considered (Table 5). The mean values of test weight did not vary significantly under different seed rates; however, highest test weight was observed with the

\section{Seed yield of lentil (kg/ha) under relay cropping:}

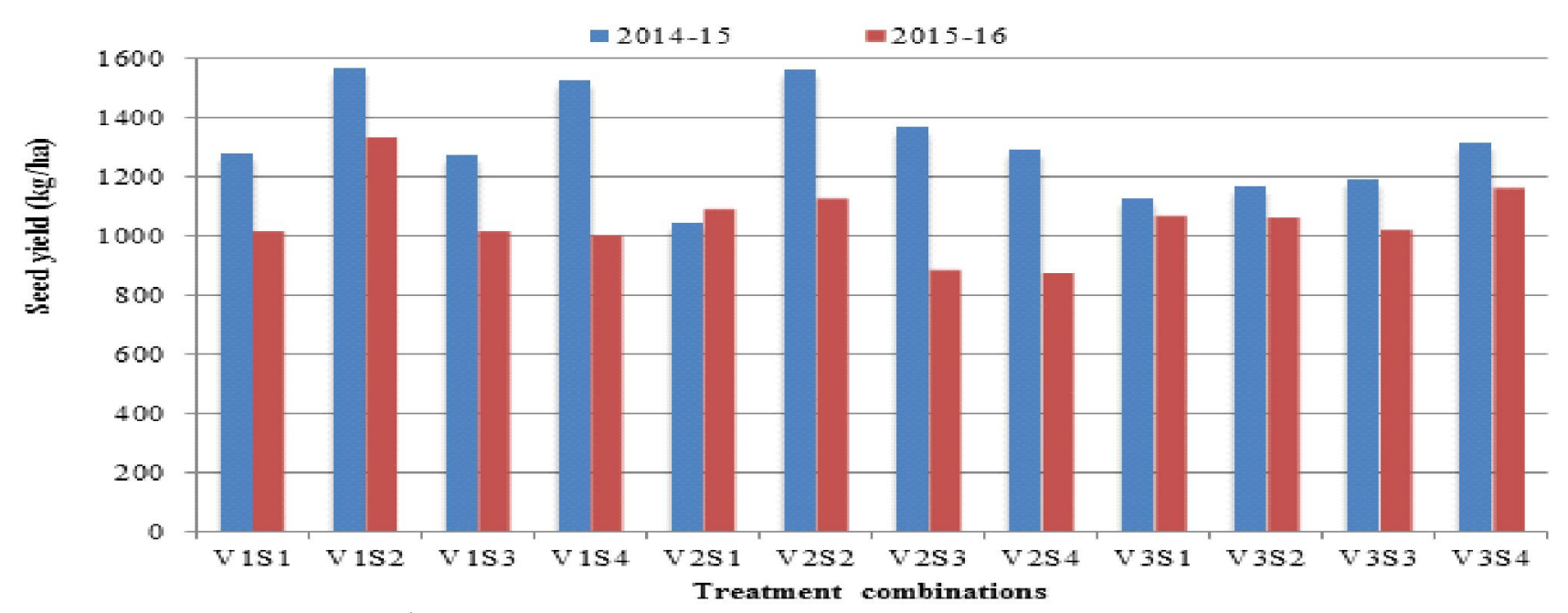

Fig-2: Seed yield of lentil $\left(\mathrm{kg} \mathrm{ha}^{-1}\right)$ under different treatment combinations in relay cropping 
seed rate of $80 \mathrm{~kg} \mathrm{ha}^{-1}$ followed by the treatment $\mathrm{S}_{2}(20.6 \mathrm{~g})$. The mean values of test weight did not vary significantly under different treatment combination. However, the variety PL 6 exhibited highest test weight (26.2 to $27.6 \mathrm{~g}$ ) under all the seed rates due to its medium bold seed character. The variety NDL 1 exhibited second best test weight (18.0 to $18.4 \mathrm{~g}$ ) followed by WBL 77 (15.1 to $16.2 \mathrm{~g}$ ).

\section{CONCLUSION}

The variety and seed rate showed significant influence on population, pods per plant, biological yield and seed yield $\left(\mathrm{kg} \mathrm{ha}^{-1}\right)$ of lentil when relay cropped after long duration rice. Under West Bengal condition, the lentil variety PL 6 performed best at $60 \mathrm{~kg} \mathrm{ha}^{-1}$ of seed rate followed by variety WBL 77 and NDL 1.

\section{REFERENCES}

Ali, Md. O., Zuberi, M. I. and Sarker, A. (2012). Lentil relay cropping in the rice-based cropping system: An innovative technology for lentil production, sustainability and nutritional security in changing climate of Bangladesh. Journal of Food Science Engineering, 2: 58 .

Ali, Md. O., Zuberi, M. I. and Sarker, A. (2014). Management practices for lentil as relay crop in the rice based cropping system. Journal of Agricultural Science and Technology, B4: 126-134.

Ayaz, S. (2001). Variability of harvest index in four grain legume species (Doctoral dissertation, Lincoln University).

El-Nagar, G.R. (2002). Effect of rhizobium inoculation, nitrogen fertilizer, seeding rates and phosphate-dissolving organism, on growth and yield of lentil. Assiut Journal of Agricultural Sciences Vol. 33 No. 3 pp. 103-114.

Gomez, K. A. and Gomez, A. A. (1984). Statistical Procedures for Agricultural Research. John Willey and Sons, Inc., New York, pp. 180.

Materne, M. and Siddique, K. H. M. (2009). Agroecology and crop adaptation. The lentil: botany, production and uses. MPG Books Group, London, 47-63.

Parveen, K. and Bhuiya, M.S.U. (2010). Effect of method of sowing and seed rate on the yield and yield components of lentil. J. Agrofor. Environ .4 (1). pp 155-157.

Parya, M., Dutta, S. K., Jena, S., Nath, R. and Chakraborty, P.K. (2010). Effect of thermal stress on wheat productivity in West Bengal.Journal of Agrometerology,12(2): 217-220.

Singh, D. P. and Singh, B. B. (1991).Evaluation of exotic germplasm in lentil. Narendra Deva Journal of Agricultural Research, 6: 304-306.

www.fao.org/faostat/en/\#data/QC 